International Journal of Agriculture and Environmental Research

ISSN: 2455-6939

Volume: 07, Issue: 06 "November-December 2021"

\title{
EVALUATION OF DIFFERENT HERBICIDES IN THE CONTROL OF BUVA AND BITTER GRASS
}

\author{
${ }^{1}$ Raphael Pereira Magalhães, ${ }^{2 *}$ Kleso Silva Franco Junior, ${ }^{3}$ Giselle Prado Brigante \\ ${ }^{1}$ Department of Fitotecnia, CESEP Machado MG, Brazil. \\ ${ }^{2}$ Department of Fitotecnia, CESEP Machado MG, Brazil. \\ ORCiD: 0000-0002-6807-8889 \\ ${ }^{3}$ Department of Fitotecnia, CESEP Machado MG, Brazil. \\ ORCiD: 0000-0002-0952-0075 \\ *Corresponding author
}

DOI: https://doi.org/10.51193/IJAER.2021.7602

Received: 22 Nov. 2021 / Accepted: 01 Dec. 2021 / Published: 02 Dec. 2021

\begin{abstract}
Weeds are characterized by occurring in unwanted places and interfering in man's interests and causing multiple damage to agricultural crops. Among the weeds frequently found in Brazilian agricultural areas, the species bittergrass (Digitaria insularis) and buva (Conyza bonariensis) have great importance in agriculture due to the selection of biotypes resistant to the main herbicide recommended, Glyphosate, with this it is necessary to study this herbicide associated with other molecules. The objective of this study was to evaluate the effect of different herbicides on the control of buva and bitter grass. The research was composed of two experiments installed in aseparably, and the experimental design was used for both randomized blocks (DBC), contained by 4 treatments and 3 replications. Experiment 1 was composed of Treatments T1 without herbicide application, T2 with Glyphosate and T3 application with Application of Glyphosate + Clethodim to evaluate the effect on bitter grass, and experiment 2 composed of 3 treatments being, T1 without herbicide application, T2 with Glyphosate application, T3 with application of Glyphosate + Saflufenacil to verify the effect on Buva. The experimental units were containers of plastic bags with a capacity of $10 \mathrm{~L}$, which were filled with 5 liters of the compound of a mixture of (70\%) ravine land with $(30 \%)$ tanned corral manure, where the seedlings of two different weed species were planted. Herbicide applications occurred
\end{abstract}


International Journal of Agriculture and Environmental Research

ISSN: 2455-6939

Volume: 07, Issue: 06 "November-December 2021"

when weeds were in full vegetative development and evaluations were performed 7, 14 and 21 days after herbicide application, and the control was evaluated visually where $0 \%$ represented the absence of apparent damage and $100 \%$ complete plant death. Then the data were submitted to analysis of variance, and the means compared by the Tukey test at $5 \%$ probability by the Software Sivar®. Thus, for the conditions of the present experiment, the treatments used can be concluded that the application of the isolated Glyphosate or associated with the herbicide Select are effective for the bitter grass, and for Buva, the use of isolated Glyphosate allows the same control when mixed with the heat, but requires a longer period of time to result in the death of the plant.

Keywords: Effectiveness; Weeds; Digitaria insularis; Conyza bonariensis

\section{INTRODUCTION}

Weeds are characterized by occurring in unwanted places and interfering in man's interests and causing multiple damage to agricultural crops. They hinder and increase costs with cultural treatments, by generating great losses in production by competition for the same resources as the culture of interest such as water, light, nutrients or physical space. The damages caused by the presence of these plants, however, do not apply only to competition, but to a set of factors such as competition itself and allelopathy, serve as hostesses of insects and diseases, besides interfering in the harvest and leaving residues at the end of the harvested product [10].

When installed in a production area, weeds cause a drop in the productivity of several crops, making it necessary to manage and control, which consequently leads to an increase in costs that represents about 20 to $30 \%$ of the production cost [13].

Although there are different means of control, the chemical control method is often used through the use of different herbicides, which becomes the most used method due to large planted areas, efficiency and high yield and reduce the cost when compared to other control methods.

Therefore, due to the process of evolution that weeds suffered due to inadequate management practices, they became resistant to certain mechanisms of action and with this many herbicides became inefficient.

Weed resistance can be understood as the ability of a given plant population to survive and reproduce after exposure to the herbicide dose that would be sufficient to kill a susceptible population of the same species [3].

A weed can become resistant when exposed to the exclusive application of a herbicide or different herbicides, but that have the same mechanism of action. Given this context, it is known 
that in the market there are many molecules with different mechanisms of action, but that due to the resistance that weeds have acquired over time, further studies are needed to evaluate the efficacy of these products.

\section{MATERIAL AND METHODS}

The research was conducted between September and November 2021 in the urban perimeter of the city of Machado-MG, located at latitude coordinates $21^{\circ} 39^{\prime} 40$ "S, longitude $45^{\circ} 55^{\prime} 30^{\prime \prime} \mathrm{W}$ and $880 \mathrm{~m}$ altitude. The region has a climate classified as Cwa according to the Koppen and Geiger classification (1948) with a defined season of hot summer and cold winter, with an average annual temperature of $20.6^{\circ} \mathrm{C}$ and a minimum of $14.7^{\circ} \mathrm{C}$, with the annual average $23.4^{\circ} \mathrm{C}$ and with relative humidity of $82.4 \%$ and the average annual precipitation $1508 \mathrm{~mm}$ [6], with the following meteorological data related to the experiment period (Table 1)

Table 1: Averages of temperature $(\mathrm{oC})$ and rainfall $(\mathrm{mm})$ data for September, October and November 2021.

\section{Machado Weather Station}

Minimum

temperature

$\left({ }^{\circ} \mathrm{C}\right)$
Average

temperature temperature $\left({ }^{\circ} \mathrm{C}\right)$

$\left({ }^{\circ} \mathrm{C}\right)$

Rainfall

$(\mathrm{mm})$

\begin{tabular}{ccccc}
\hline September & 13.6 & 31.8 & 19.8 & 0.6 \\
\hline October & 14 & 26.6 & 17.4 & 10.2 \\
\hline November & 15.02 & 26.4 & 20.71 & 7.52 \\
\hline * Machado Weather Station - MG & & &
\end{tabular}

The research was composed of two experiments installed in a part, and the experimental design was used for both randomized blocks (DBC). Experiment 1 consisted of 3 treatments: T1 without herbicide application (control), T2 with application of Glyphosate (GLIFOSATO- 380g L-1 of acid equivalent at the dosage of 3 L ha-1), T3 with application of Glyphosate (GLYPHOSAte$380 \mathrm{~g} \mathrm{~L}-1$ of acid equivalent at the dosage of $3 \mathrm{~L}$ ha-1) + Clethodim (Cletodim $-240 \mathrm{~g} \mathrm{~L}-1$ of acid equivalent at dosage $0.45 \mathrm{~L}$ ha-1 ). These treatments were composed of 4 replications, totaling 12 
International Journal of Agriculture and Environmental Research

ISSN: 2455-6939

Volume: 07, Issue: 06 "November-December 2021"

experimental plots, where two bitter grass seedlings (Digitaria insularis (L)) were planted for a plot of approximately $30 \mathrm{~cm}$ of compliance, and herbicides were applied in each treatment.

Experiment 2 was composed of the T1 treatment without herbicide application (control), T2 with application of Glyphosate (GLIFOSAtE- 380g L-1 of acid equivalent at the dosage of $3 \mathrm{~L}$ ha-11), T3 with application of Glyphosate (GLYPHOSate- 380g L-1 of acid equivalent at the dosage of $3 \mathrm{~L}$ ha-1 + Saflufenacil (SAFLUFENACIL - 700g Kg-1 of acid equivalent at the dosage of 40 $\mathrm{g}$ ha-1. In the use of the herbicide Saflufenacil a non-ionic adjuvant was added at $0.5 \% \mathrm{v} / \mathrm{v}$, as recommended in the package leaflet. The treatments were installed in 4 replicates, totaling 12 experimental plots. In each plot, two seedlings of the species of the weed Buva (Conyza bonariensis) were planted with approximately $25 \mathrm{~cm}$ of compliance, where the herbicides of each treatment were applied.

The experimental units were containers of plastic bags with a capacity of $10 \mathrm{~L}$, which were filled with 5 liters of the compound of a mixture of (70\%) ravine land with (30\%) tanned corral manure, where the seedlings of two different weed species were planted. The containers were arranged in an open area and watered manually three times a week with $300 \mathrm{~mL}$ of water in each watering.

Weed seedlings were collected in the Machado-MG region, and after being collected, with approximately $15 \mathrm{~cm}$ and were transplanted to the containers that constituted the experimental plots referring to experiment 1 and experiment 2 .

Herbicide applications occurred when weeds were in full vegetative development, and environmental conditions were favorable with less wind possibility to avoid drift during application, care was also taken to achieve success and safety in the application and high activity of the product as recommended by [4]. The herbicides were applied in a directed jet, using a costal sprayer equipped with teejet 11002 tip with pressure of 2 bar.

The evaluation of the effect of herbicides was performed 7 and 14 and 21 days after herbicide application, and the evaluation of the control was performed in a visual way where $0 \%$ will represent the absence of apparent damage and 100\% the complete death of the plant [12].

The data were submitted to analysis of variance, and the means compared by the Tukey test at $5 \%$ probability by the Software Sivar® [5].

\section{RESULTS AND DISCUSSION}

Experiment 1: The evaluations were carried out 7, 14 and 21 days after herbicide application, and the evaluation of the control was performed visually where $0 \%$ represented the absence of 
International Journal of Agriculture and Environmental Research

ISSN: 2455-6939

Volume: 07, Issue: 06 "November-December 2021"

apparent damage and 100\% represented the complete death of the plant [12], condorme shown in the (Table 2).

The chemical control provided by the herbicides applied on the bitter grass plots in the first seven days after application provided efficacy (> 80\% control) for the treatments when compared to the control treatment, where there was no chemical control ( $0 \%$ control) (Table 2$)$.

At seven days after application, the treatment composed of Glyphosate + Clethodim has already reached 100\% control (Table 2), completely eliminating weeds, however, follow-up was performed through evaluations 14 and 21 days after application, for observation regarding regrowth at its base, and also to monitor the Glyphosate application process alone. However, no regrowth was observed at the base of the plants after 21 days.

The efficacy of the herbicide Select is related to its mechanism of action that has the characteristic of paralyzing the cell division of plants, and after a few days of its application cause the exchange of pigments of the leaves of plants, leaving it with yellowish color and then causing death completely [4].

At 14 days after the application of Glyphosate isolation ally, there was progress of the effectiveness from $80 \%$ of control to $92.5 \%$. And at 21 days after application, complete death of plants was observed (Table 2). This effect on bitter grass plants is caused by the action of chichemical acid, because the herbicide acts on the route of this acid preventing the action of the enzyme 5- enolpiruvil-chiquimate-3-phosphate-synthase (EPSPs), causing the application of glyfosate, absorption and translocation occurs rapidly and intensively, generating accumulation in areas of active growth, this accumulation causes the paralysis of growth and degradation of plant functions, causing the death of plant tissues [7].

Glyphosate is characterized by being a systemic herbicide, non-selective and post-emergent, which is absorbed by plants through their leaves and their caulculae, and soon after absorption, the transport of this herbicide reaches all plant structures and causes the blocking of the metabolism of amino acids [9] causing the complete death of plants, when the resistance mechanism is not developed.

At 21 days after application, all treatments presented statistically similar results, except for the control treatment that there was no herbicide application (Table 2), thus the efficacy of the treatments for the weed in question was observed.

The glyphosate used in this experiment is the most widely used herbicide in the world, due to the high use in recent years by the increasing adoption of herbicide tolerant transgenic crops and the 
ease of its use, as it has low toxicity, low cost, broad control spectrum and rapid adsorption in the soil [11], caused plants resistant to this molecule to be selected, as with bitter grass plants.

The reduction of the effectiveness of the control in many cases is related to the use of the same herbicide molecule for several consecutive times, which leads to the selection of weeds to this, making inefficient its action on the plant [3] for the coditions of the present experiment, the application of Glyphosate both isolated and in mixture with Select herbicide provided similarly effective control.

Although bitter grass is a weedknown as resistant to the application of applied Glyphosate in isolation, the efficacy of this application may be related to the use of seedlings collected in the experiment region, which may be a species not yet resistant. However, [2] evaluating chemical control alternatives of adult plants of $D$. insularis, observed different results, since the control with Glyphosate application alone was ineffective for the weed that recovered after being treated with the herbicide.

Table 2: Effect of herbicide application on bitter grass (Digitaria insularis L) 7, 14 and 21 days after application.

\begin{tabular}{cccc}
\hline Treatment & 7 days after application & $\begin{array}{c}\text { 14 days after } \\
\text { application }\end{array}$ & $\begin{array}{c}21 \text { days after } \\
\text { application }\end{array}$ \\
\hline Witness & $0 \mathrm{~B}$ & $0 \mathrm{~B}$ & $0 \mathrm{~B}$ \\
\hline Glyphosate & $80 \mathrm{~A}$ & $92,5 \mathrm{~A}$ & $100 \mathrm{~A}$ \\
\hline Glyphosate +Clethodim & $100 \mathrm{~A}$ & $100 \mathrm{~A}$ & 8,33 \\
\hline $\mathrm{CV}(\%)$ & 38,49 & 13,5 & $\mathrm{~A}$ \\
\hline
\end{tabular}

*Averages followed by the same letters do not differ statistically from each other by the Tukey test at $5 \%$ probability.

Experiment 2: The evaluations were performed 7, 14 and 21 days after herbicide application, and the visual control was evaluated where $0 \%$ represented the absence of apparent damage and $100 \%$ represented the complete death of the plant [12], as shown in (Table 5).

For the weed of the species Conyza bonariensis (Buva), the chemical control provided by the herbicide Glyphosate at 7 days after application provided control of 37.5\%, which caused a yellowish effect on the plant but not the effective control, which differed statistically from the 
application of the combination between Glyphosate + Saflufenacil that provided control with $100 \%$ efficacy in the same time period (Table 3 ).

It can be observed that the herbicide Saflufenacil based on saflufenacil, presented rapid contact action, causing cell death, and completely eliminating the weed when compared with glyphosate that resulted in the slowest translocation, since the plants submitted to glyphosate application only had lower efficacy (Table 3).

Report that the application of saflufenacil-based herbicides in mixture with glyphosate allows the best efficacy in the control of buva and also prevents weed recovery.

The use of the herbicide Saflufenacil is effective to control the main weeds, and to assist in the management of resistance to broad leaves, because its formulation contains the active Saflufenacil, which is a molecule developed to control weeds difficult to control in several crops [1]. This herbicide has an action mechanism that blocks the action of the enzyme protoporphyrinogen oxidase (PPO or PROTOX) and allows the death of plants by inhibiting this enzyme, causing sensitive tissues to necrotise rapidly [8]. Thus, the use of this molecule associated with Glyphosate allows the positive effect on the control, as observed in Table 3.

At 14 afterGlyphosate application alone, total efficacy was observed with $100 \%$ control, differing statistically after this periodonlyfromthe control treatment (Table 3), where there was no herbicide application and as a consequence the plants only developed.

As Glyphosate is a non-selective product, responsible for blocking the activity of the enzyme 5enolpiruvil-chiquimate-3-phosphate synthase (EPSPS), and also for the synthesis of the amino acids tryptophan, phenylalanine and tyrosine [14]. After its application, there is immediate translocation through the phloem that leads to the death of the plant. 
International Journal of Agriculture and Environmental Research

ISSN: 2455-6939

Volume: 07, Issue: 06 "November-December 2021"

Table 3: Effect of herbicide application on Buva (Conyza bonariensis)

7,14 and 21 days after application.

\begin{tabular}{cccc}
\hline Treatment & $\begin{array}{c}7 \text { days after } \\
\text { application }\end{array}$ & $\begin{array}{c}\text { 14 days after } \\
\text { application }\end{array}$ & $\begin{array}{c}21 \text { days after } \\
\text { application }\end{array}$ \\
\hline Witness & $0 \mathrm{C}$ & $0 \mathrm{~B}$ & $0 \mathrm{~B}$ \\
\hline Glyphosate & $37.5 \mathrm{~B}$ & $100 \mathrm{~A}$ & $100 \mathrm{~A}$ \\
\hline Glyphosate + Saflufenacil & $100 \mathrm{~A}$ & $100 \mathrm{~A}$ & $100 \mathrm{~A}$ \\
\hline $\mathrm{CV}(\%)$ & 11,49 & 0,00 & 3,71
\end{tabular}

*Averages followed by the same letters do not differ statistically from each other by the Tukey test at $5 \%$ probability.

\section{CONCLUSION}

It is concluded that the conditions of the present experiment, the application of Glyphosate isolated or associated with the herbicide Cletodim are effective for bitter grass.

For Buva, the use of glyphosate alone allows the same control when mixed with Saflufenacil, but requires a longer period of time to provide the death of the plant.

\section{REFERENCES}

[1] BASF. Saflufenacil@: Herbicida para soja e outrasculturas, 2018. Disponívelem: <https://agriculture.basf.com/br/pt/protecao-de-cultivossementes/produtos/heat.html >. Acessoem: 07 maio 2021.

[2] CORREIA, N. M., DURIGAN, J. C. Manejoquímico de plantasadultas de Digitaria insularis com glyphosate isolado e emmistura com chlorimuron-ethyl ouquizalofop-pterurilemárea de plantiodireto. Bragantia,v. 68, n.3, p. 689-697, 2009.

[3] CHRISTOFFOLETI, P.J.; LÓPEZ-OVEJERO, R. F. Principais aspectos da resistência de plantas daninhasao herbicida glyphosate. Planta Daninha, v.21, n.3, p.507-515, 2003.

[4] EMPRESA BRASILEIRA DE PESQUISA AGROPECUÁRIA-EMBRAPA. Época de aplicação de herbicidasna cultura do milho. Embrapatrigo, 2006.

[5] FERREIRA, D. F. Sisvar: um guia dos seus procedimentos de comparaçõesmúltiplas Bootstrap. Ciência e agrotecnologia.v. 38, n.2, p. 109-112. 2014.

[6] MACHADO CLIMA, Climate-data.ORG. 2021-Disponível em: >https://pt.climatedata.org/america-do-sul/brasil/minas-gerais-203/<acesso 29/06/2021 às 06:55 
[7] MAY, A., VIANA, R., DOS SANTOS, M., DA SILVA, E. Aplicação de glyphosate nadessecação do sorgo biomassa. RevistaBrasileira de Herbicidas, v. 15, n. 4, p. 362370, dez. 2016.

[8] OLIVEIRA, JR. R.S. 2011. Biologia e manejo de plantasdaninhas. Disponívelem; <http://omnipax.com.br/livros/2013/BFRM/bfrm-cap01.pdf>Acessoem: 07 maio 2021.

[9] Toledo, M.Z.; Cavariani, C.; França-Neto, J.B. Qualidade fisiológica de sementes de soja colhidas em duas épocas após dessecação com glyphosate. Revista Brasileira de Sementes, v.34, n.1, p.134-142, 2012.

[10] VASCONCELOS, M. C. C.; SILVA, A. F. A. DA; LIMA, R. DA SILVA. Interferência de Plantas Daninhassobre Plantas Cultivadas. Agropecuaria cientifica no semiarido, v. 8, n. 1, p. 1-6, 2012.

[11] VELINI, E. D. et al. Modo de ação do glyphosate. In: VELINI, E. D. et al. Glyphosate. Botucatu: Fundação de Estudos e Pesquisas Florestais, p. 113-133, 2009.

[12] VILELA, D.; COBUCCI, T.; HAEINEMANN, A. B.; REIS, F. A.; PEREIRA, A. V.; FERREIRA, R. de P. Avaliação da eficiência de herbicida no controle de plantasdaninhasemalfafa. Ciência Agrotécnica, Lavras, v. 28, n. 4, p. 729-735, 2004.

[13] VIVIAN, R. A importância das plantasdaninhasnaagricultura. 2011. Disponívelem: $<$ https://www.paginarural.com.br/artigo/2236/a-importancia-das-plantas-daninhasnaagricultura $>$. Acesso: 06 maio 2021.

[14] ZABLOTOWICZ, R. M.; REDDY, K. N. Nitrogenase activity, nitrogen content, and yield responses to glyphosate in glyphosate-resistant soybean. Crop Protection, Guildford, v. 26, n. 3, p. 370-376, 2007. 